\title{
Diabetes Unawareness in Patients Hospitalized Other Than Internal Medicine Services and Related Factors: A Cross-Sectional Multidisciplinary Study
}

\author{
Dahiliye Servisi Dışında Hastanede Yatan Hastalarda \\ Bilinmeyen Diyabet ve Illişkili Faktörler: Multidisipliner \\ Kesitsel bir Çalışma
}

Elif Yildirim Ayaz ${ }^{1}$, Memduha Boyraz², Mirac Vural Keskinler ${ }^{3}$, Ayse Naciye Erbakan ${ }^{3}$, Aytekin Oguz $^{3}$

1 University of Health Sciences, Sultan Abdülhamid Han Training and Research Hospital, Internal Medicine Clinic, Istanbul, Turkey

${ }^{2}$ Vezirköprü State Hospital, Internal Medicine Clinice, Samsun, Turkey

${ }^{2}$ Istanbul Medeniyet University, SB Goztepe Prof Dr Suleyman Yalcin City Hosptal, Internal Medicine, Istanbul, Turkey

Address correspondence to: Elif Yildirim Ayaz, University of Health Sciences, Sultan Abdülhamid Han Training and Research Hospital, Internal Medicine Clinic, İstanbul, Turkey

e-mail: drelifyildirim@hotmail.com

Geliş Tarihi/Received: 27 April 2021 Kabul Tarihi/Accepted: 1 June 2021

\begin{abstract}
Öz
Amaç: Bu çalışmanın amacı dahiliye dışındaki servislerde yatan hastalarda tanı konulmamış diyabet prevalansının belirlenmesi ve diyabet farkındalığının olmaması ile ilişkili faktörlerin değerlendirilmesidir. Hastalar ve Yöntem: Bu çok merkezli, tanımlayıcı, kesitsel çalışma dahili ve cerrahi kliniklerde yatmakta olan 630 katılımcı ile yapılmıştır. Katılımcıların antropometrik ölçümleri, glukoz ve HbA1c ölçümleri yapılmıştır. Bilinen diyabet tanısı olmayıp yatışı sırasında $\mathrm{HbA} 1 \mathrm{c}$ değeri $\geq 6,5 \%$ olanlar diyabet farkındalığı olmayanlar olarak tanımlanmıştır.

Bulgular: Bilinen diyabeti olanların sayısı 190 iken (\%30,2), $396(\% 62,9)$ kișinin diyabeti yoktu, $44(\% 7)$ hastada ise bilinmeyen diyabet saptandı. Diyabet farkındalığı olmayanlarda bilinen diyabet grubundakilere göre fazla oranda genç $(<45$ yaş) ve erkek hasta vardı $(p<0.01, p<0.05)$. Diyabet farkındalığı olmayanlarda fazla kilolu olanların ve komorbiditesi olmayanların oranı bilinen diyabetlilerden daha yüksekti $(p<0,01$, $\mathrm{p}: 0.01)$. Çok değişkenli lojistik regresyon analizi erkek cinsiyet, $<45$ yaş, aşırı kilolu olma ve komorbidite olmamasının diyabet ile ilişkili olduğunu gösterdi.

Sonuç: Hastanede iç hastalıkları servisi dışında yatmakta olan hastaların \%7'sinde tanı konulmamıs diyabet saptanmıştır. Tüm diyabetlilerin \%18.8'i diyabet olduğunu bilmemektedir. Yatan hastalarda HbA1c ile diyabet taraması yapmak, $<45$ yaş, erkek, fazla kilolu ve komorbiditesi olmayan hastalara özellikle dikkat etmek, bilinmeyen diyabeti saptamaya yardımcı olabilir.

Anahtar Kelimeler: Diabetes mellitus, Hb A1c, yatan hastalar, teşhis tarama programları Abstract

Aim: The aim of the study is to investigate the prevalence of diabetes unawareness in patients hospitalized in clinics other than internal medicine and evaluate the factors associated with them.

Patients and Methods: This multi-center, descriptive, cross-sectional study was conducted

with 630 participants who were inpatients of internal and surgical clinics The participants' anthropometric measurements, glucose and $\mathrm{HbA} 1 \mathrm{c}$ measurements were made. Those without a known diabetes diagnosis but with an $\mathrm{HbA} 1 \mathrm{c}$ value of $\geq 6.5 \%$ were grouped as diabetes unaware.

Results: The number of the patients with known diabetes was $190(30.2 \%), 396(62.9 \%)$ did not have diabetes, and unknown diabetes was detected in $44(7 \%)$. There were a higher rate of young ( $<45$ years) and male patients in those with diabetes unawareness than those in the known diabetes group $(p<0.01$, $p<0.05$ ). The rate of overweight and absence of comorbidity were higher in the diabetes unaware group than known diabetics. $(p<0.01, p: 0.01)$. The multivariate logistic regression analysis showed that the male sex, age $<45$ years, being overweight and absence of a comorbidity were associated with diabetes unawareness.

Conclusion: Undiagnosed diabetes was detected in $7 \%$ of the patients. Among all diabetics, $18.8 \%$ had diabetes unawareness. Conducting diabetes screening with $\mathrm{HbA} 1 \mathrm{c}$ in inpatients and paying special attention to those under 45, males, overweight patients and those without comorbidities may help detect unknown diabetes.

Key words: Diabetes mellitus, $\mathrm{Hb}$ A1c, inpatients, diagnostic screening programs
\end{abstract}

Cite this article as: Yildirim Ayaz E, Boyraz M, Keskinler MV, Erbakan AN, Oguz A Diabetes Unawareness in Patients Hospitalized Other Than Internal Medicine Services and Related Factors: A Cross-Sectional Multidisciplinary Study. Selcuk Med J 2021;37(2): 137-145
Disclosure: None of the authors has a financial interest in any of the products, devices, or drugs mentioned in this article. The research was not sponsored by an outside organization. All authors have agreed to allow full access to the primary data and to allow the journal to review the data if requested. 


\section{INTRODUCTION}

Diabetes is a significant cause of mortality and morbidity due to the macrovascular and microvascular complications it may cause, and its prevalence is increasing worldwide $(1,2)$. In 2019, all throughout the world, about half of the diabetic patients between the ages of 20-79 years did not know that they had diabetes (3). While the prevalence of unknown diabetes among diabetic individuals in high-income countries is $38.3 \%$, this rate reaches $66.8 \%$ in low-income countries (3). In the TURDEP-2 study conducted in Turkey in 2010, the prevalance of unknown diabetes in all diabetic patients was $55 \%$ (4). With the development of diagnosis and treatment methods throughout the years, the mortality of diabetic individuals in the United States decreased by $20 \%$ per decade (5). Although complications like end-stage renal failure, acute myocardial infarction, stroke, and lower extremity amputation are preventable with early diagnosis and treatment, the inadequacy of diagnosis leads diabetes to continue to be a significant public health problem and a global economic burden $(6,7)$. A study conducted in Luxemburg found that $62 \%$ of patients without diabetes awareness had moderatehigh risk of cardiovascular disease according to the Framingham risk scoring system (8). More screening is needed to increase awareness of diabetes. A significant accessible population for diabetes screening consists of patients staying at hospitals.

Determining those with diabetes unawareness and organizing diabetes care and treatment can shorten patients' hospitalization and reduce mortality (9). Previous studies have reported the undiagnosed diabetes rate in inpatients as $5-24 \%(10,11)$. While the diabetes prevalance is also high in the inpatients of units other than internal medicine services, diagnosis is frequently overlooked, and studies in this field are few. A study conducted on patients hospitalized for coronary heart disease or elective joint replacement surgery found the dysglycemia rate in those without a diagnosis of diabetes as $10-11 \%$ (12). A study conducted at an orthopedics clinic reported that $4 \%$ of patients did not know that they had diabetes (13). Assessment of inpatients concerning the presence of diabetes will not only reduce the number of undiagnosed diabetic patients in society but also allow these patients to receive higher-quality and appropriate healthcare services individually. To our knowledge, there is not any multidisciplinary study that has included patients from all units except for internal medicine and conducted screening on these patients in the literature.

Hyperglycemia may be associated with other factors than diabetes, such as stress hyperglycemia, in inpatients $(14,15)$. Therefore it is not feasible to use glucose concentrations for the diagnosis of diabetes in inpatients. It will be more appropriate to use $\mathrm{HbA1c}$ in the diagnosis of diabetes for this specific population $(14,15)$. Although several conditions may affect $\mathrm{HbA} 1 \mathrm{c}$, as it does not require fasting and is not affected by the sudden change in blood glucose, it provides a better advantageous alternative in inpatients (16).

Defining the characteristics of individuals without diabetes awareness may help determine especially patients that need to be tested. In Turkey and many populations, women, the elderly and those with comorbidities are examined more frequently due to various diseases, and they become aware of their diseases. We think that being male and being young are a risk factor in terms of diabetes unawareness. Moreover, obese patients are frequently examined for diabetes, and diabetes is often overlooked in normal weight and overweight patients. A low education level is also a risk factor for diabetes unawareness (17). In a study conducted in Korea, diabetes awareness was higher in men and those over the age of 60 (18). Steven et al. (19) observed that diabetes awareness increased along with working hours, age and presence of family history. There is a need for comprehensive studies that are conducted to investigate whether or not there are differences between inpatients without diabetes awareness and those with known diabetes diagnosis in terms of age, sex, education status, presence of comorbidities and body mass index (BMI).

We aim to investigate the prevalence of undiagnosed diabetes in patients hospitalized at services other than internal medicine services by checking $\mathrm{HbA} 1 \mathrm{c}$ and to assess whether or not there are differences between those without diabetes awareness and those with known diabetes diagnosis concerning age, sex, education status, presence of comorbidities and BMI. We hypothesize that diabetes unawareness is common in patients hospitalized other than internal medicine service, and those who do not know about their diabetes are more likely male, non-obese, younger, have a low education level and have no-comorbidity. We think defining the unknown diabetes prevalance and associated risk factors in inpatients will specifically determine patients who need to be screened, and this will improve healthcare. 


\section{PATIENTS AND METHODS}

This multi-center, descriptive, cross-sectional study was conducted at Sultan Abdülhamid Han Training and Research Hospital and Göztepe Training and Research Hospital located in İstanbul, between April 20 and December 31, 2017.

\section{Sample}

Participants in the main cohort included those who were inpatients of internal and surgical clinics other than internal medicine and internal medicine sub-specialty services, at or over the age of 18 , who volunteered to participate in the study, whose anthropometric measurements could be made, went through clustered random sampling method performed by a computer. The computer program enumerates the items in the sampling frame, determines its own random numbers, and presents the selected items to the researcher in writing or digitally (20). The internal clinics included neurology, dermatology, physiotherapy and rehabilitation, cardiology, infectious diseases, and pulmonology services, while the surgical clinics comprised of general surgery, cardiovascular surgery, pulmonary surgery, orthopedics and traumatology, brain surgery, ophthalmology, urology, gynecology, and plastic surgery services. Electronic medical records of the patients were examined. Also, anamnesis was taken from the patients and their doctor. Patients who had comorbidities that could affect their anthropometric measurements (e.g., heart failure, edema, liver cirrhosis, cancer, cachexia, and Cushing syndrome), those who had been using steroids for more than a month, those who were pregnant, those in the postoperative period, those with conditions altering the $\mathrm{HbA1c}$ (such as sickle cell disease, glucose-6phosphate dehydrogenase deficiency, hemodyalysis, recent blood loss or transfusion, or erythropoietin therapy) were excluded from this study. Data of 3220 patients randomly selected from hospital records were obtained. 1105 patients who met the inclusion criteria were evaluated. After being evaluated for exclusion criteria, 802 patients remained eligible for the study. Of the 634 patients who gave consent to participate in the study, 4 patients could not complete the anthropometric measurements. The study was completed with 630 participants.

Participants wishing to participate in the study were informed about study objectives, procedures and data privacy, and were told that participation was voluntary, and they could withdraw from the study at any time. Approval was taken from the University of
Medeniyet, Göztepe Training and Research Hospital Ethics Committee (approval number: 2017/038) before the study commenced. Also institution approval were obtained from the institution to which the health institutions where this study was conducted were affiliated. The participants were informed about the research topic in line with the "Declaration of Helsinki", and their consent was obtained by stating that the data obtained from this study would be used only within the scope of this research; privacy and confidentiality would be provided. This study was registered at the Protocol Registration and Results System (Clinicaltrials.gov PRS) with the registration number NCT04694326. The Strengthening the Reporting of Observational Studies in Epidemiology (STROBE) checklist was used in the preparation of this article.

\section{Data Collection and Variables}

The participants' age, sex, education level, employment status, comorbidities (hypertension, cardiovascular disease, hyperlipidemia, heart failure, chronic kidney disease, hyperthyroidism, hypothyroidism, chronic obstructive pulmonary disease, asthma, cancer, other chronic disease) unit of hospitalization, and inpatient diagnosis were recorded. Their recorded diagnoses in the hospital system and the Ministry of Health's system were accessed, International Classification of Disease-10 (ICD-10) codes were examined, the epicrisis was read in detail, anamnesis was taken including sociodemographic properties and medical history from the patient, and known diseases were also asked of their doctor. The prescription records in the Ministry of Health's system were also examined, and whether they used antidiabetic drugs was checked. Height, weight, and waist circumference measurements were taken. Anthropometric measurements of patients were performed with light clothes and without shoes and headwear. Weight was evaluated in an upright position by a calibrated scale. The heights of the patients were measured with a standard-height ruler while standing with their back touching the height ruler. Waist circumference was measured with flexible tape, the midpoint between the lower rib margin and the iliac crest, after the patient exhaled. Fasting blood glucose and $\mathrm{HbA1c}$ values were assessed. The $\mathrm{HbA1c}$ test was conducted with the Boronate affinity HPLC method using a Trinity Biotech Premier Hb9210 device.

Waist circumference classified according to cutoff values for central obesity for European adults (21). It 
was categorized as high if $\geq 80 \mathrm{~cm}$ in women and $\geq 94$ $\mathrm{cm}$ in men, and it was considered normal otherwise. BMI $\left(\mathrm{kg} / \mathrm{m}^{2}\right)$ was calculated based on height $(\mathrm{kg})$ and weight $\left(\mathrm{m}^{2}\right)$.

BMI values of $<25 \mathrm{~kg} / \mathrm{m}^{2}$ were recorded as underweight-normal, $25-29.99 \mathrm{~kg} / \mathrm{m}^{2}$ were categorized as overweight, and $\geq 30 \mathrm{~kg} / \mathrm{m}^{2}$ were categorized as obese. American Diabetes Association (ADA) recommends that individuals without a known risk be screened beginning at the age of 45 , but they may still have diabetes even if they are younger (16). Therefore patients who were younger than 45 years were also evaluated separately to see their diabetes risk and characteristics. Education level was categorised as illiterate, primary school, high scool and university.

History of previous diabetes diagnosis reported by the patient and/or doctor, the medications they used, and diagnoses recorded in the system were examined, and those with known diabetes were collected in the 'Known Diabetes' group. Among those with no previously known diagnosis of diabetes, those with an $\mathrm{HbA} 1 \mathrm{c}$ value of $\geq 6.5 \%$ were categorized in the 'Diabetes Unaware' group, while those with an
$\mathrm{HbA} 1 \mathrm{c}$ value of $<6.5 \%$ were categorized in the 'No Diabetes' group. As stress hyperglycemia could not be excluded in inpatients, glucose values were not used for diagnostic purposes. HbA1c measurement, which is not based on glucose measurement, which is one of the standard diagnostic criteria determined by the ADA, was used for detecting diabetes (16).

\section{Outcomes}

Outcomes of interest included determinig the prevalence of diabetes unawareness in hospital; defining whether or not there are differences between those without diabetes awareness and those with known diabetes diagnosis concerning age, sex, education status, presence of comorbidities and BMI; examining risk factors affecting diabetes unawareness.

\section{Statistical analysis}

To determine the sample size, a power analysis was conducted in the GPower 3.1 program by taking into consideration the values of the data obtained from a similar study in the literature. The required sample size [alpha] at an effect size of 0.5 and error level of .05 was determined as 630 . The strength of

Table 1. Distribution of Sociodemographic Characteristics, and Anthropometric Measurements and Comorbidity Status

\begin{tabular}{|c|c|c|}
\hline Variables & & N (\%) \\
\hline \multirow[t]{3}{*}{ Age (years) } & MeantSD (Min-Max) & $58.04 \pm 18.56(18-94)$ \\
\hline & $<45$ years & $145(\% 23.0)$ \\
\hline & $\geq 45$ years & $485(\% 77.0)$ \\
\hline \multirow[t]{2}{*}{ Gender } & Female & $286(45.4)$ \\
\hline & Male & $344(54.6)$ \\
\hline Weight (kg) & Mean $\pm S D($ Min-Max) & $76.56 \pm 14.58(40-134)$ \\
\hline \multirow[t]{6}{*}{ Body Mass Index $\left(\mathrm{kg} / \mathrm{m}^{2}\right)$} & Underweight & $18(2.9)$ \\
\hline & Normal weight & $174(27.6)$ \\
\hline & Overweight & $244(38.7)$ \\
\hline & Obesity Class 1 & $127(20.2)$ \\
\hline & Obesity Class 2 & $52(8.3)$ \\
\hline & Obesity Class 3 & $15(2.4)$ \\
\hline Waist Circumference $(\mathrm{cm})$ & Mean $\pm S D($ Min-Max) & $94.07 \pm 14.39(60-149)$ \\
\hline \multirow[t]{2}{*}{ Female } & Normal & $38(13.3)$ \\
\hline & High & $248(86.7)$ \\
\hline Waist Circumference $(\mathrm{cm})$ & Mean $\pm S D($ Min-Max) & $94.07 \pm 14.39(60-149)$ \\
\hline \multirow[t]{2}{*}{ Male } & Normal & $170(49.4)$ \\
\hline & High & $174(50.6)$ \\
\hline \multirow[t]{4}{*}{ Education Level } & Illeterate & $81(12.8)$ \\
\hline & Primary School & $350(55.6)$ \\
\hline & High School & $114(18.1)$ \\
\hline & University & $85(13.5)$ \\
\hline \multirow[t]{5}{*}{ Employment Status } & Working & $239(37.9)$ \\
\hline & Not Working & $8(1.3)$ \\
\hline & Retired & $146(23.2)$ \\
\hline & Homemaker & $229(36.3)$ \\
\hline & Student & $8(1.3)$ \\
\hline \multirow[t]{2}{*}{ Comorbidity } & No & $176(27.9)$ \\
\hline & Yes & $54(71.1)$ \\
\hline
\end{tabular}


the analysis with this sample size was found to be $90.2 \%$. The NCSS (Number Cruncher Statistical System) 2007 (Kaysville, Utah, USA) software was used for the statistical analyses. While analyzing the data obtained in this study, in addition to descriptive statistical methods (mean, standard deviation, median, frequency, ratio, minimum, maximum), oneway ANOVA was used to compare three or more groups showing normal distribution in the quantitative data. In contrast, the Bonferroni test and the GamesHowell test were used to determine the group causing the difference. In comparing three or more groups not showing normal distribution, the Kruskal Wallis test was used, whereas the Dunn-Bonferroni test was used to determine the group causing the difference. Pearson's chi-squared and Fisher Freeman Halton tests were used in comparing the qualitative data. Logistic regression analysis was used to determine risk factors affecting diabetes unawareness. $p<0.05$ was accepted as statistically significant.

\section{RESULTS}

The mean age of the 630 patients was $58.0 \pm 18.6$ years, while $54.6 \%(n=344)$ were male. The patients' mean weight was $76.7 \pm 14.6 \mathrm{~kg}$, and their mean BMI was $27.9 \pm 5.5 \mathrm{~kg} / \mathrm{m} 2$. This study included $274(43.5 \%)$ patients were included from surgical units, and 356 $(56.5 \%)$ patients from non-surgical units. Table 1 shows the distribution of the sociodemographic characteristics, anthropometric measurements and comorbidity status of the participants.

While the number of those with known diabetes was 190 (30.2\%), 396 (62.9\%) did not have diabetes, and $44(7 \%)$ had undiagnosed diabetes. Of the 234 patients with diabetes, $18.8 \%$ ( $\mathrm{n}: 44)$ were not aware of their diabetes. Table 2 presents the assessment of sociodemographic characteristics, anthropometric measurements, comorbidity status and laboratory findings based on the presence of diabetes.

While there was no significant difference between the mean ages of those with known diabetes and the diabetes unaware group, the mean ages of both groups were higher than that of the no diabetes group (65.7 $\pm 10.7,65.3 \pm 13.9,53.6 \pm 20.5, p<0.01$, respectively). When 45 years of age was used as a cut-off point, the percentage of patients unaware of their diabetes were higher than the patients with known diabetes $(11.4 \%$ vs. $3.7 \%)(p<0.01)$. When

Table 2. Assessment of Sociodemographic Characteristics, Anthropometric Measurements, Comorbidity Status and Laboratory Findings Based on the Presence of Diabetes

\begin{tabular}{|c|c|c|c|c|c|}
\hline & \multicolumn{3}{|c|}{ Diabetes Presence } & \multirow{2}{*}{$\begin{array}{l}\text { Test Value } \\
p\end{array}$} \\
\hline & & $\begin{array}{l}\text { Known } \\
\text { n (\%) }\end{array}$ & $\begin{array}{l}\text { Unaware } \\
\text { n (\%) }\end{array}$ & $\begin{array}{l}\text { No Diabetes } \\
\text { n (\%) }\end{array}$ & \\
\hline \multirow[t]{2}{*}{ Age (years) } & $\begin{array}{l}\text { Mean } \pm S D \\
<45 \text { years }\end{array}$ & $\begin{array}{l}65.7 \pm 10.7 \\
7(3.7)\end{array}$ & $\begin{array}{l}65.3 \pm 13.9_{a} \\
5(11.4)_{b}\end{array}$ & $\begin{array}{l}53.6 \pm 20.5 \mathrm{~b} \\
133(33.6)^{\circ}\end{array}$ & ${ }^{\mathrm{b}} 0.001^{* *}$ \\
\hline & $\geq 45$ years & $183(96.3)_{a}$ & $39(88.6)_{b}$ & $263(66.4)_{\mathrm{c}}^{\mathrm{c}}$ & ${ }^{\mathrm{b}} 0.001^{* *}$ \\
\hline Sex & $\begin{array}{l}\text { Female } \\
\text { Male }\end{array}$ & $\begin{array}{l}99(52.1)_{b} \\
91(47.9)_{b}\end{array}$ & $\begin{array}{l}14(31.8)^{a} \\
30(68.2)\end{array}$ & $\begin{array}{l}173(43.7)_{\mathrm{b}} \\
223(56.3)_{\mathrm{b}}\end{array}$ & ${ }^{\mathrm{a}} 0.027^{*}$ \\
\hline Weight (kg) & Mean $\pm S D$ & $79.6 \pm 14.1$ & $83.2 \pm S 12.7$ & $74.4 \pm 14.6_{b}^{b}$ & ${ }^{\mathrm{b}} 0.001^{* *}$ \\
\hline BMI (kg/m) & $\begin{array}{l}\text { Underweight-Normal } \\
\text { Overweight } \\
\text { Obese }\end{array}$ & $\begin{array}{l}36(18.9)_{a}^{a} \\
72(37.9)_{a}^{a} \\
82(43.2)_{a}^{a}\end{array}$ & $\begin{array}{l}3(6.8)_{\mathrm{b}} \\
25(56.8)_{\mathrm{b}} \\
16(36.4)_{\mathrm{b}}\end{array}$ & $\begin{array}{l}153(38.6)_{\mathrm{c}} \\
147(37.1)_{\mathrm{c}} \\
96(24.2)_{\mathrm{c}}\end{array}$ & ${ }^{\mathrm{d}} 0.001^{* *}$ \\
\hline Waist & Mean $\pm S D$ & $102.9 \pm 14.4_{a}$ & $102.9 \pm 11.8$ & $91.7 \pm 15.7_{b}$ & b $0.001^{* *}$ \\
\hline Circumference & Normal & $2(2)_{a}$ & $0(0)_{a}$ & $36(20.8)_{b}$ & ${ }^{\mathrm{b}} 0.001^{* *}$ \\
\hline Female & High & $97(98)_{a}$ & $14(100)_{a}$ & $137(79.2)_{b}$ & \\
\hline Waist & Mean $\pm S D$ & $101.5 \pm 13.7_{a}$ & $103.7 \pm 9.7$ & $91.7 \pm 15.7_{b}$ & ${ }^{\mathrm{b}} 0.001^{* *}$ \\
\hline Circumference & Normal & $25(27.5)_{a}$ & $4(13.3)_{a}$ & $141(63.2)_{b}^{b}$ & b 0.001 ** \\
\hline Male & High & $66(72.5)_{a}^{a}$ & $26(86.7)_{a}$ & $82(36.8)_{b}$ & \\
\hline \multirow[t]{4}{*}{ Education Status } & Illiterate & $34(17.9)$ & $3(6.8)$ & $44(11.1)$ & ${ }^{\mathrm{a} 0} 0.152$ \\
\hline & Primary School & 107 (56.3) & $26(59.1)$ & 217 (54.8) & \\
\hline & High School & $30(15.8)$ & $8(18.2)$ & $76(19.2)$ & \\
\hline & University & $19(10)$ & $7(15.9)$ & $59(14.9)$ & \\
\hline \multirow[t]{2}{*}{ Comorbidity } & No & $20(10.5)_{a}$ & $11(25)_{b}$ & $145(36.6)_{b}$ & ${ }^{\mathrm{a}} 0.001^{*}$ \\
\hline & Yes & $170(89.5)_{\mathrm{a}}$ & $33(75)_{b}$ & $251(63.4)_{b}$ & \\
\hline Glucose $(\mathrm{mg} / \mathrm{dL})$ & MeanıSD & $159.8 \pm 73.2 \mathrm{a}$ & $137 \pm 54$ & $91.6 \pm 18.4_{b}$ & ${ }^{\circ} 0.001^{* *}$ \\
\hline $\mathrm{HbA} 1 \mathrm{c}(\%)$ & Mean $\pm S D$ & $8.08 \pm 2.01_{a}$ & $7.23 \pm 1.35_{b}$ & $5.6 \pm 0.41_{c}$ & ${ }^{\circ} 0.001^{* *}$ \\
\hline
\end{tabular}

\footnotetext{
Different letters next to the frequencies and Mean \pm SD indicate significantly different columns.
}

apearson's Chi-Squared Test, b One-way ANOVA, 'Kruskal Wallis Test, ${ }^{\mathrm{d}}$ Fisher-Freeman-Halton Test ${ }^{*} p<0.05{ }^{* *} \mathrm{p}<0.01$ 
compared by gender, significantly more male patients were in the diabetes unaware group $(68.2 \%)$ than the known diabetes group $(47.9 \%)(p<0,05)$. There was no such difference between diabetes unaware and no diabetes (56.3\%) groups ( $p: 0.13)$.

There was a significant difference among the groups based on their distributions of BMI categories. The rate of the overweight individuals in the diabetes unaware group (56.8\%) was significantly higher than those in the known diabetes (37.9\%) and no diabetes $(39.1 \%)$ groups ( $p<0.01$ for both). The mean weight of the known diabetes group (79.6 \pm 14.1$)$ was similar to that of the diabetes unaware group $(83.2 \pm 12.7)$ and significantly higher than that of the no diabetes group $(74.4 \pm 14.6)(p<0.01)$. Among both the men and the women, while the waist circumference was similar between known diabetes and diabetes unaware groups, it was higher in both of these groups than the no diabetes group ( $p<0.01$ for both). The waist circumference was high among all women in the diabetes unaware group and $98 \%$ of the women in the known diabetes group. The percentages of high waist circumference were $86.7 \%$ and $72.5 \%$ for men, respectively. In the no diabetes group, the high waist circumference rates were $79.2 \%$ in the women and $36.8 \%$ in the men, and these rates were significantly lower compared to the other two groups $(p<0.01$ for both).

There was no significant difference among the three groups concerning their educational levels. While comorbidities were more frequently observed in the known diabetes group $(89.5 \%)$ than the diabetes unaware group (75\%), it was similar between those in the diabetes unaware group and the no diabetes group (63.4\%) (p:0.01, p:0.13, respectively). There was no significant difference between the fasting glucose measurements of the known diabetes and diabetes unaware groups. The mean $\mathrm{HbA} 1 \mathrm{c}$ value of the diabetes unaware group $(7.2 \pm 1.4)$ was lower than that of the known diabetes group (8.1 \pm 2.0$)$ (p:0.02). Logistic regression analysis for diabetes unawareness and risk factors

The effect of gender, <45 years old, BMI, high waist circumference, and absence of comorbidity on diabetes unawareness among all diabetic patients was also evaluated by logistic regression analysis (Table 3). Male gender, <45 years, being overweight and absence of comorbidity were associated with diabetes unawareness.

\section{DISCUSSION}

In this study, where we investigated new diabetes detection frequency in inpatients hospitalized in clinics other than internal medicine services by checking $\mathrm{HbA} 1 \mathrm{c}$, the diabetes unawareness prevalence was $7 \%$. Approximately one-fifth of the diabetic patients were unaware of their diabetes. The male sex, age $<45$ years, being overweight and absence of a comorbidity were associated with diabetes unawareness, while education level had no significant relationship to diabetes unawareness.

A study conducted in the United States in 2017 among the general public found the undiagnosed diabetes frequency as 3\% (22). In their analysis, the findings showed that the diagnosed diabetics led to an economic burden of 327 billion dollars per year, while undiagnosed diabetics created a financial burden of 43 billion dollars per year (22). Detection and treatment of undiagnosed diabetic individuals in society will reduce this economic burden by preventing complications that will be created by diabetes in the future and allow individuals to have a higher-quality of life. Furthermore, applying current treatment will reduce cardiovascular diseases and mortality $(23,24)$. Finding the diabetes unawareness prevalence as $7 \%$ in the entire inpatient population and $18.8 \%$ in the diabetic population in our study suggest that undiagnosed patients are still a real obstacle for

Table 3. Logistic regression analysis for diabetes unawareness and risk factors

\begin{tabular}{|c|c|c|c|c|c|}
\hline & \multirow[t]{2}{*}{ B } & \multirow[t]{2}{*}{$\mathbf{p}$} & \multirow[t]{2}{*}{ ODDS } & \multicolumn{2}{|c|}{$95 \%$ C.I.for ODDS } \\
\hline & & & & Lower & Upper \\
\hline Sex (Male) & 0,85 & $<0,05^{*}$ & 2,33 & 1,16 & 4,67 \\
\hline Age (<45 years) & 1,21 & $<0,05^{*}$ & 3,35 & 1,01 & 11,1 \\
\hline BMI (overweight) & 0,77 & $<0,05^{*}$ & 2,16 & 1,11 & 4,19 \\
\hline High WC (female) & 19,27 & 0,999 & 233161326,7 & 0,00 & \\
\hline High WC (male) & 0,90 & 0,12 & 2,46 & 0,78 & 7,77 \\
\hline Comorbidity (no) & 1,04 & 0,013 & 2,83 & 1,24 & 6,46 \\
\hline \multicolumn{6}{|c|}{ WC: Waist Circumference, BMI: Body Mass Index ${ }^{*} p<0,05$} \\
\hline
\end{tabular}


diabetes treatment, and public health screenings are inadequate.

Not only public screenings but also in-hospital screenings are in need of improvement. In a study where the records of patients hospitalized who had hyperglycemia were investigated, it was observed that only $62 \%$ of those without a diagnosis of diabetes but had hyperglycemia were tested for $\mathrm{HbA} 1 \mathrm{c}$, and undiagnosed diabetes was detected in $58 \%$ of those whose $\mathrm{HbA} 1 \mathrm{c}$ values were checked (25). As stress hyperglycemia may lead to high glucose levels in inpatients, glucose measurement is inadequate for the diagnosis of diabetes. In a study where $\mathrm{HbA1c}$ measurement, glucose measurement, and oral glucose tolerance test (OGTT) were conducted among those with high risk concerning diabetes in patients admitted to the hospital by emergency services, the findings showed that $\mathrm{HbA} 1 \mathrm{C}$ was more sensitive in identifying undiagnosed diabetes in comparison to the other tests (26).

Detection of undiagnosed diabetic individuals by HbA1c screening may shorten hospital stays and reduce mortality by guiding treatment arrangements. It should be kept in mind to screen for diabetes by $\mathrm{HbA} 1 \mathrm{c}$ testing in inpatients. Sentell et al. (27) determined known diabetes in $30.5 \%$ and undiagnosed diabetes in $3.4 \%$ of inpatients at a major medical center in Hawaii, and they found that those with undiagnosed diabetes had more hospitalizations, prolonged hospital stay, and in-hospital mortality than those with known diabetes.

According to the National Health and Nutrition Examination Survey (NHANES), the male gender ratio is higher in undiagnosed diabetic individuals than in those who are diagnosed (28). Furthermore, in a study conducted for screening by $\mathrm{HbA} 1 \mathrm{c}$ measurement in pneumonia patients in the general public, the male gender was associated with undiagnosed diabetes to a 2.5-fold higher extent (29). In our study, the rate of men in the diabetes unaware group was higher than twice the number of women, and the percentage of male patients was significantly higher than those of the known diabetes and no diabetes groups. Our findings supported the data from previous studies. A study conducted in Germany also found the ratio of the male gender in undiagnosed diabetes patients higher than the known diabetes group, and the patients in the undiagnosed group were also younger (30). Similarly, in our study, patients under the age of 45 were more likely to be unaware of their diabetes than the known diabetes group.
A high waist circumference is one of the most significant risk factors for diabetes (31). In our study, there was no significant difference between the known diabetes group and the diabetes unaware group regarding their waist circumference values. In the diabetes unaware group, $86.7 \%$ of the male and all females had high waist circumference values. A meta-analysis that included epidemiological studies in the last 15 years reported that even the average waist circumference values in Turkey were higher than the limit values (32). Therefore, a high waist circumference value becomes no longer a distinctive characteristic in the Turkish population.

In the Hispanic Community Health Study, being overweight was determined to be associated with undiagnosed diabetes (33). Similarly, Bantie et al. (34) found a relationship between undiagnosed diabetes and being overweight. However, in our study, the frequency rate of being overweight in the undiagnosed diabetes group was higher than that in the known diabetes group. This finding can be explained by that overweight patients are frequently overlooked while obese patients are commonly screened for diabetes.

In a study investigating the relationship between social inequalities and unknown diabetes, the findings showed that those with a higher education level had a 1.5 times higher risk of undiagnosed diabetes than those with a low education level (35). A study conducted in Bangladesh found that patients with undiagnosed diabetes had lower education levels (17). A cross-sectional study in the United States determined a higher rate of unknown diabetes among individuals without access to health insurance and health services (36). In our study, the education levels were not different between the known diabetic and undiagnosed diabetic individuals. While individuals from every socioeconomic class can directly and freely access even tertiary health institutions, and everyone frequently gets tested in Turkey might affect this result, having obtained the data only from two hospitals' patient populations limits this inference.

The finding in our study that diabetes unawareness is higher among those without comorbidities can be attributed to those individuals who visit hospitals due to any disease are also tested for other diseases, including diabetes. While the fasting glucose levels were similar between known diabetes and diabetes unaware groups in this study, the $\mathrm{HbA1c}$ levels were higher in the known diabetes group. HbA1c is one of the most significant biomarkers of diabetes complications (37). Those with higher HbA1c levels 
visit hospitals with diabetes complications more frequently might affect this result.

\section{Limitations and Strengths}

Our study had many limitations. First of all, this study was conducted at only two different tertiary hospitals in Istanbul. Including other hospitals from different regions of Turkey might give a better understanding of the situation. However, this is still an exemplary study where HbA1c screening has been performed by including patients from several clinics units at the included hospitals. Our study did not assess the risk factors for diabetes development, such as social isolation, physical inactivity, and dietary habits. Additionally, $\mathrm{HbA} 1 \mathrm{c}$ measurement is influenced by situations like anemia, blood transfusion, massive blood loss, and hemolysis, which would only lead to underdiagnosing of diabetes (16). Patients with these medical situations were excluded from the study but were still not examined for these conditions.

One of the strengths of our study was that this study involved data from several different clinics. In our research, by excluding internal medicine services and internal medicine subspecialities services, we included patients from all other surgical and internal services at the hospitals. To our knowledge, there is no study in the literature that has conducted $\mathrm{HbA} 1 \mathrm{c}$ screening by including patients from all surgical and internal units except for internal medicine services. We believe our research will raise awareness of the necessity for non-internist physicians to take part in the diagnosis of diabetes. Additionally, we think that all procedures that have been used in this study are easily accessible and applicable and will provide an advantage in reflecting the results on practice.

\section{CONCLUSION}

In conclusion, $\mathrm{HbA} 1 \mathrm{c}$ was checked in the inpatients of clinics other than internal medicine services, and undiagnosed diabetes was determined in $7 \%$ of the patients. This study showed that $18.8 \%$ of all diabetic patients had diabetes unawareness. The undiagnosed diabetic patients were more likely to be younger than 45 years of age, male, overweight and have no comorbidities. Conducting diabetes screening with $\mathrm{HbA} 1 \mathrm{c}$ in inpatients and paying particular attention to those under 45, males, overweight patients, and those without comorbidities may help detect unknown diabetes. Further studies are needed on the prevalence of diabetes unawareness and related factors.
Conflict of interest: Authors declare that there is no conflict of interest between the authors of the article.

Financial conflict of interest: Authors declare that they did not receive any financial support in this study.

Address correspondence to: Elif Yildirim Ayaz, University of Health Sciences, Sultan Abdülhamid Han Training and Research Hospital, Internal Medicine Clinic, Istanbul, Turkey

Phone Number: +902165422020

e-mail: drelifyildirim@hotmail.com

\section{REFERENCES}

1. Zheng Y, Ley SH, Hu FB. Global aetiology and epidemiology of type 2 diabetes mellitus and its complications. Nat Rev Endocrinol 2018;14(2):88-98.

2. Yilmaz MB, Kiliçkap $M$, Abaci $A$, et al. Temporal changes in the epidemiology of diabetes mellitus in Turkey: A systematic review and meta-analysis. Turk Kardiyol Dern Ars 2018;46(7):546-55.

3. International Diabetes Foundation. IDF Diabetes Atlas 2019.; 2019. http://www.idf.org/about-diabetes/facts-figures

4. Satman I, Tutuncu Y, Gedik S. The TURDEP-II Study Group, Diabetes epidemic in Turkey: Results of the second population based survey of diabetes and risk characteristics in Turkey (TURDEP-II). Diabetologia 2011;54.

5. Gregg EW, Cheng $Y J$, Srinivasan $M$, et al. Trends in cause-specific mortality among adults with and without diagnosed diabetes in the USA: An epidemiological analysis of linked national survey and vital statistics data. Lancet 2018;391(10138):2430-40.

6. Gregg EW, Li Y, Wang J, et al. Changes in diabetes-related complications in the United States, 1990-2010. N Engl J Med 2014;370(16):1514-23.

7. Bommer C, Heesemann E, Sagalova V, et al. The global economic burden of diabetes in adults aged 20-79 years: A cost-of-illness study. Lancet Diabetes Endocrinol 2017;5(6):423-30.

8. Alkerwi A, Pagny S, Lair ML, et al. Level of unawareness and management of diabetes, hypertension, and dyslipidemia among adults in Luxembourg: Findings from ORISCAV-LUX Study. PLoS One. 2013;8(3).

9. Bąk E, Marcisz C, Krzemińska S, et al. Relationships of sexual dysfunction with depression and acceptance of illness in women and men with type 2 diabetes mellitus. Int J Environ Res Public Health 2017;14(9):1-14.

10. Nanayakkara $\mathrm{N}$, Nguyen $\mathrm{H}$, Churilov $\mathrm{L}$, et al. Inpatient $\mathrm{HbA} 1 \mathrm{c}$ testing: A prospective observational study. BMJ Open Diabetes Res Care 2015;3(1):4-10.

11. Mazurek JA, Hailpern SM, Goring T, et al. Prevalence of hemoglobin A1C greater than $6.5 \%$ and $7.0 \%$ among hospitalized patients without known diagnosis of diabetes at an Urban Inner City Hospital. J Clin Endocrinol Metab 2010;95(3):1344-8.

12. Malcolm JC, Kocourek J, Keely E, et al. Implementation of a screening program to detect previously undiagnosed dysglycemia in hospitalized patients. Can $\mathrm{J}$ Diabetes 2014;38(2):79-84.

13. Ekinci El, Kong A, Churilov L, et al. Using automated HbA1c testing to detect diabetes mellitus in orthopedic inpatients 
and its effect on outcomes. PLoS One 2017;12(1):1-12.

14. Maclntyre EJ, Majumdar SR, Gamble JM, et al. Stress hyperglycemia and newly diagnosed diabetes in 2124 patients hospitalized with pneumonia. Am J Med 2012;125(10):1036. e17-23.

15. Ali Abdelhamid $Y$, Kar P, Finnis ME, et al. Stress hyperglycaemia in critically ill patients and the subsequent risk of diabetes: A systematic review and meta-analysis. Crit Care 2016;20(1):1-9.

16. American Diabetes Association. 2. Classification and Diagnosis of Diabetes: Standards of Medical Care in Diabetes-2021. Diabetes Care 2021;44(Supplement 1):S1533.

17. Volaco A, Cavalcanti AM, Filho RP, et al. Socioeconomic status: The missing link between obesity and diabetes mellitus? Curr Diabetes Rev 2018;14(4):321-6.

18. Boo S, Yoon YJ, Oh H. Evaluating the prevalence, awareness, and control of hypertension, diabetes, and dyslipidemia in Korea using the NHIS-NSC database: A cross-sectional analysis. Med (United States) 2018;97(51):e13713.

19. Yen ST, Tan AKG, Mustapha FI. Awareness of diabetes, hypertension, and hypercholesterolemia in Malaysia. J Diabetes 2017;9(9):874-83.

20. Newman I, Benz CR, Ridenour CS. Qualitative-quantitative research methodology: Exploring the interactive continuum. SIU Press, 1998.

21. Alberti KGMM, Zimmet $P$, Shaw J. The metabolic syndrome A new worldwide definition. Lancet 2005;366(9491):1059-62.

22. Dall TM, Yang W, Gillespie K, et al. The economic burden of elevated blood glucose levels in 2017: Diagnosed and undiagnosed diabetes, gestational diabetes mellitus, and prediabetes. Diabetes Care 2019;42(9):1661-8.

23. Marso S, Daniels G, Brown-Frandsen K, et al. Liraglutide and cardiovascular outcomes in type 2 diabetes. $\mathrm{N}$ Engl $\mathrm{J}$ Med 2016;375(4):311-22.

24. Zinman B, Wanner C, Lachin JM, et al. Empagliflozin, cardiovascular outcomes, and mortality in type 2 diabetes. $\mathrm{N}$ Engl J Med 2015;373(22):2117-28.

25. Jones D, Scharfenberg B, Perkins J, et al. Glycated hemoglobin testing to identify undiagnosed diabetes mellitus in the inpatient setting. J Am Osteopath Assoc 2016;116(6):350-7.

26. Manley SE, O'Brien KT, Quinlan D, et al. Can HbA1c detect undiagnosed diabetes in acute medical hospital admissions? Diabetes Res Clin Pract 2016;115:106-14.

27. Sentell TL, Cheng Y, Saito E, et al. The burden of diagnosed and undiagnosed diabetes in Native Hawaiian and Asian American hospitalized patients. J Clin Transl Endocrinol 2015;2(4):115-24.

28. Zhang $N$, Yang $X$, Zhu $X$, et al. Type 2 diabetes mellitus unawareness, prevalence, trends and risk factors: National Health and Nutrition Examination Survey (NHANES) 19992010. J Int Med Res 2017;45(2):594-609.

29. Jensen AV, Faurholt-Jepsen D, Egelund GB, et al. Undiagnosed diabetes mellitus in community-acquired pneumonia: A prospective cohort study. Clin Infect Dis 2017;65(12):2091-8.

30. Du Y, Baumert J, Paprott R, et al. Factors associated with undiagnosed type 2 diabetes in Germany: Results from German Health Interview and Examination Survey for Adults 2008-2011. BMJ Open Diabetes Res Care 2020;8(1).

31. Seo DC, Choe S, Torabi MR. Is waist circumference $\geq 102 / 88$ $\mathrm{cm}$ better than body mass index $\geq 30$ to predict hypertension and diabetes development regardless of gender, age group, and race/ethnicity? Meta-analysis. Prev Med (Baltim) 2017;97:100-8.

32. Ural D, Kiliçkap M, Göksülük H, et al. Data on prevalence of obesity and waist circumference in Turkey: Systematic review, meta-analysis and meta-regression of epidemiological studies on cardiovascular risk factors. Turk Kardiyol Dern Ars 2018;46(7):577-90.

33. Casagrande SS, Menke A, Aviles-Santa L, et al. Factors associated with undiagnosed diabetes among adults with diabetes: Results from the hispanic community health study/ study of latinos (HCHS/SOL). Diabetes Res Clin Pract 2018;146:258-66.

34. Bantie GM, Wondaye AA, Arike EB, et al. Prevalence of undiagnosed diabetes mellitus and associated factors among adult residents of Bahir Dar city, northwest Ethiopia: A community-based cross-sectional study. BMJ Open 2019;9(10):e030158.

35. Moody A, Cowley G, Fat LN, et al. Social inequalities in prevalence of diagnosed and undiagnosed diabetes and impaired glucose regulation in participants in the Health Surveys for England series. BMJ Open 2016;6(2):e010155.

36. Selvin E, Wang $D$, Lee $A K$, et al. Identifying trends in undiagnosed diabetes in U.S. Adults by using a confirmatory definition: A cross-sectional study. Ann Intern Med 2017;167(11):769-76.

37. Campbell L, Pepper T, Shipman K. HbA1c: A review of nonglycaemic variables. J Clin Pathol 2019;72(1):12-9. 